\title{
Assessment of Groundwater Quality for Drinking Purpose in an Industrial Area, Dumai City, Riau, Indonesia
}

\author{
Fitri Mairizki $^{1 *}$, Risti Putri Angga ${ }^{2}$, Arief Yandra Putra ${ }^{3}$ \\ ${ }^{1,2}$ Department of Geological Engineering, Faculty of Engineering, Univeristas Islam Riau, Pekanbaru, Indonesia. \\ ${ }^{3}$ Department of Chemistry Education, Faculty of Teacher Training and Education, Universitas Islam Riau, Pekanbaru, Indonesia.
}

\author{
* Corresponding author : fitrimairizki@eng.uir.ac.id \\ Tel.: +62-853-7897-3771; \\ Received: Dec 6, 2020; Accepted: Dec 22, 2020 \\ DOI 10.25299/jgeet.2020.5.4.5983
}

\begin{abstract}
Groundwater is the main water resource especially for daily water needs. Population growth and urbanization have increased demand for water while the availability of groundwater has decreased both in quality and quantity. Various human activities also produce industrial, agriculture and municipal waste that can pollute groundwater through leaching process. The purposes of this study are to determine the quality of groundwater around tofu industrial factory and its evaluation for drinking water based on Health Minister Regulation No.492/MENKES/PER/IV/2010 and Government Regulation No.82 2001. The temperature, pH, total dissolved solids (TDS) and electrical conductivity (EC) were measured by using YSI-Pro. Chemical Oxygen Demand (COD) and Biochemical Oxygen Demand (BOD) were measured based on SNI 06-6989.2.2009 test method and SNI 06-698.72.2009 test method, respectively. Physically, groundwater had temperature average $28,6^{\circ} \mathrm{C}$, TDS $243 \mathrm{mg} / \mathrm{L}$ and EC $396 \mu \mathrm{S} / \mathrm{cm}$. Almost all groundwater were acidic with $\mathrm{pH}$ average 5,6 and did not meet the drinking water quality requirements. Groundwater had COD average $78 \mathrm{mg} / \mathrm{L}$, BOD average $36 \mathrm{mg} / \mathrm{L}$ and it were classified into moderate-heavy pollution. It indicated that groundwater may have been contaminated by organic material from tofu industrial wastewater. Therefore, groundwater should not be used as a source of drinking water.
\end{abstract}

Keywords: Groundwater, Industrial Area, Drinking Water, COD, BOD

\section{Introduction}

Clean water is a basic human need that has a direct impact on the physical, social and economic well-being of community. In Indonesia, generally clean water comes from water surface, groundwater, and rain water. The availability of fresh water is very limited while sea water cannot be used directly because it contains salt in high concentration (Nurhalisaetal., 2017). Groundwater is the main water resource especially for daily water needs. Groundwater has many advantages compared to other water resources. Groundwater is not affected by the season and relatively easy to obtain. Although water is a renewable natural resource, it is limited depending on space and time.

Population growth and urbanization have increased demand for water while the availability of groundwater has decreased both in quality and quantity. Various human activities also produce industrial, agriculture and municipal waste that can pollute groundwater through leaching process. Pollutants can be in the form of heavy metals, organic substances and suspended solids which are under certain concentration endanger the environment and human health directly or indirectly. Groundwater pollution due to industrial activities has become a concern of various countries in the world (Sharma et al., 2016); (Rout and Baldev, 2018); (Samira et al., 2019); (DurgasrilaksmiH., 2019).

Groundwater is suitable for consumption if it meets the requirements set out by International and National regulations. These requirements consist of mandatory and additional parameters including physical, chemical and biological components. Physically, drinking water must be clear, tasteless and odorless. Drinking water must also be free from impurities in chemicals and organic materials. (Risky D.,P., et al., 2017). The study about groundwater quality as drinking water have been carried out by many researchers (Annapoorna and Janardhana, 2015); (Lalitha, B.V., Teja, V.S., Rajesh, V., 2016);(Khan A., and Khan M.A., 2018); (Naslilmuna, M., Muryani, C., Santoso, S., 2018); (Ibrahim, 2019); (Putra, A.,Y., and Mairizki, F., 2020).

The study area is area around tofu industrial factory whose liquid waste is directly disposed of into environment without prior treatment. Tofu industrial liquid waste contains a lot of organic compounds that can cause contamination of groundwater used by the surrounding community. It is important to monitor the groundwater quality regularly and continuously to ensure that groundwater free from contaminants and suitable for consumption. Therefore, the research aims are to determine the quality of groundwater around tofu industrial factory and its evaluation for drinking water based on Health Minister Regulation N0.492/MENKES/PER/IV/2010 and Government Regulation No.82 2001.

\section{Study Area}

Bukit Batrem area is located in East Dumai district, Dumai city, Riau. Based on regional geological map, Dumai is located in the Central Sumatra Basin which composed by two formations, young superficial deposits (Qh) and older superficial deposits (Qp). Stratigraphy of the study area consist of old superficial deposits (Qp) with Plistocene-aged rocks. Rocks in the research area are clay, silt, clay gravels and vegetation rafts (Fig.1).

Groundwater samples were obtained from 25 dug wells around the tofu industrial factory (Fig.2). Physically, groundwater are cloudy-browns and smells. Liquid waste from tofu factory is immediately disposed of without treatment. Therefore, it is feared that the liquid waste can contaminate the 
environment including groundwater that used by community around the area.

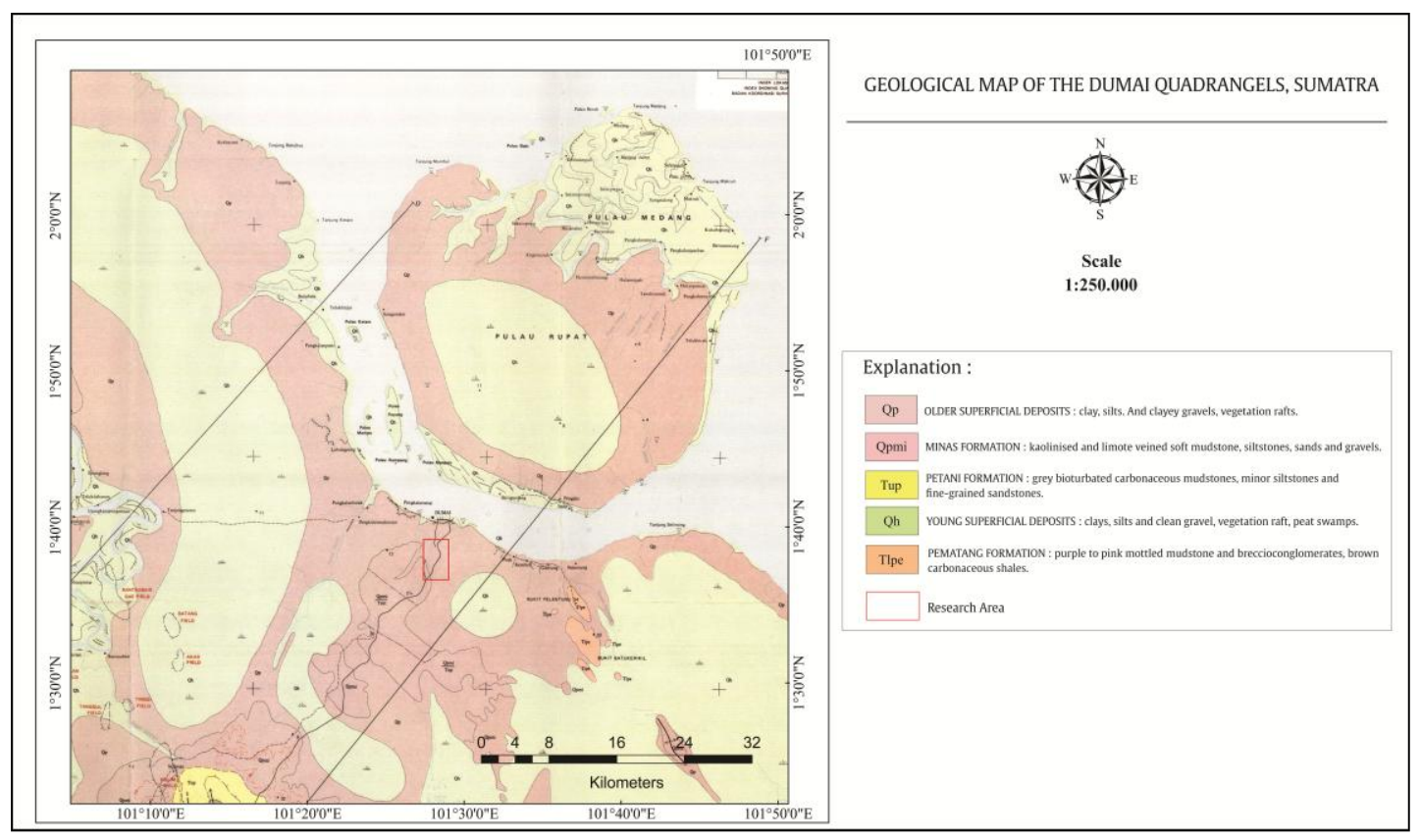

Fig. 1. Regional geological map of research area

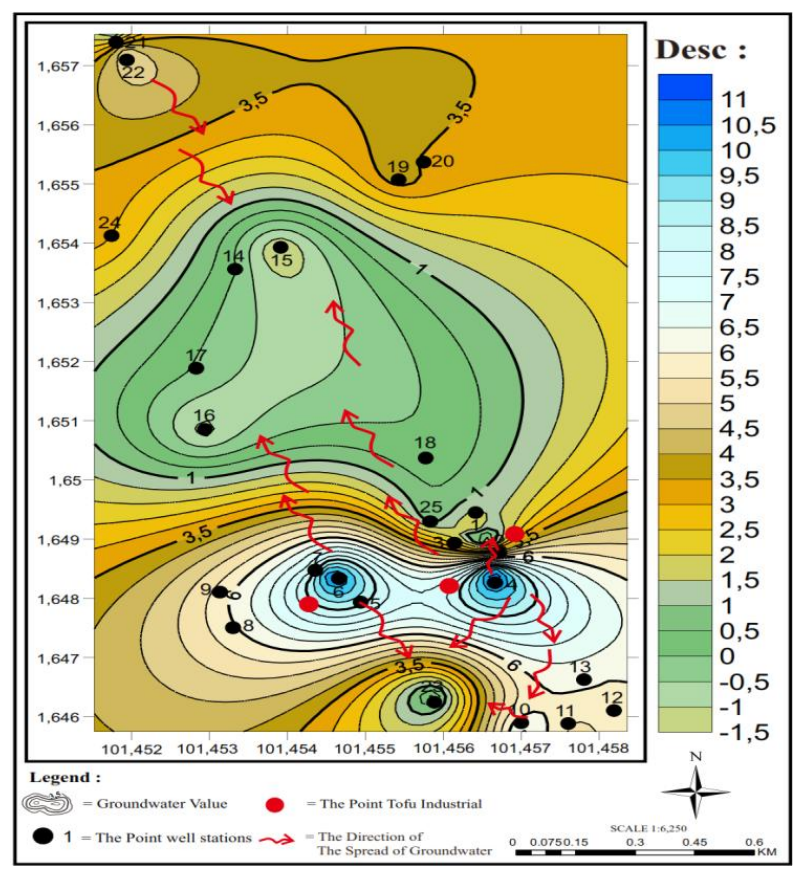

Fig 2. Groundwater flow direction map of research area

\section{Methodology}

The groundwater samples were taken from 25 dug wells around tofu industrial factory in Bukit Batrem area, East Dumai district, Dumai city, Riau. Physical parameters were examined in the Geological Engineering Laboratory Universitas Islam Riau, while chemical parameters were examined in the Industrial Research and Standardization Laboratory Padang. The temperature, $\mathrm{pH}$, total dissolved solids (TDS) and electrical conductivity (EC) were measured by using YSI-Pro. Chemical Oxygen Demand (COD) and Biochemical Oxygen Demand (BOD) were measured based on SNI 06-6989.2.2009 test method and SNI 06-698.72.2009 test method, respectively. The results then compared with the Health Minister Regulation
N0.492/MENKES/PER/IV/2010 about drinking water quality requirements and Government Regulation No.82 2001 about water quality management and water pollution control.

\section{Results and Discussion}

\subsection{Geological Condition of Study Area}

In the research area, there were 25 dug well stations and 3 tofu factories that located in the middle of the research area. The geological condition of study area was dominated by peat soil. Peat is a type of soil that formed through the accumulation of semi decomposed plants. This causes the color of groundwater to be yellow-brown and had an acidic $\mathrm{pH}$. Poor drainage and 
the distance between wells and drainage that does not meet the requirements also causes groundwater in study area to smell.

\subsection{Temperature}

The groundwater temperature in the research area ranges from $26-30^{\circ} \mathrm{C}$ with average $28.6^{\circ} \mathrm{C}$ and still meets the standard Drinking water temperature standard based on Health Minister Regulation was the air temperature $\pm 3^{\circ} \mathrm{C}$. Water temperature greatly influences the chemical, physical and biological processes that occur in the water. High water temperature indicates the decomposition of organic compounds or the dissolution of chemical compounds such as phenols and sulfur (Mairizki, F., and Cahyaningsih, C., 2016) Water temperature can be affected by several factors such as season, latitude, altitude, cloud cover, water flow and depth.

\section{3. $\mathrm{pH}$}

Almost all groundwater $\mathrm{pH}$ values (96\%) were less than 6,5 with average 5,6. Groundwater $\mathrm{pH}$ standard according to Health Minister Regulation was 6,5-8,5. Groundwater in research area were acidic. This can be due to the geological conditions in that area and dissolving result of weathering rocks in tropical area rarely produce water $\mathrm{pH}$ above 7 . Changes in the $\mathrm{pH}$ of water can cause changes in smell, taste, and color. Drinking water should be neutral, not acidic/alkaline, to prevent dissolution of heavy metals and corrosion of drinking water distribution network. Groundwater with a low $\mathrm{pH}$ can dissolve iron metal, causing the groundwater to turn yellowish (Putra, A.Y., and Mairizki, F.,2019)

\subsection{Total Dissolved Solid (TDS)}

TDS value of groundwater ranges from $30-350 \mathrm{mg} / \mathrm{L}$ with average $243 \mathrm{mg} / \mathrm{L}$. All groundwater had TDS value below 500 $\mathrm{mg} / \mathrm{L}$ and meet the standard according to Health Minister Regulation. All of groundwater also included in freshwater (TDS 0-1000 mg/L) (Putra, D.B.E et al., 2019).

Dissolved solids can be derived from organic or inorganic compounds that are dissolved in water such as sulfate, chloride and magnesium salts. Dissolved solids can also from tofu industrial wastewater around research area. The presence of TDS can change the taste of water (Firdaus et al., 2017).

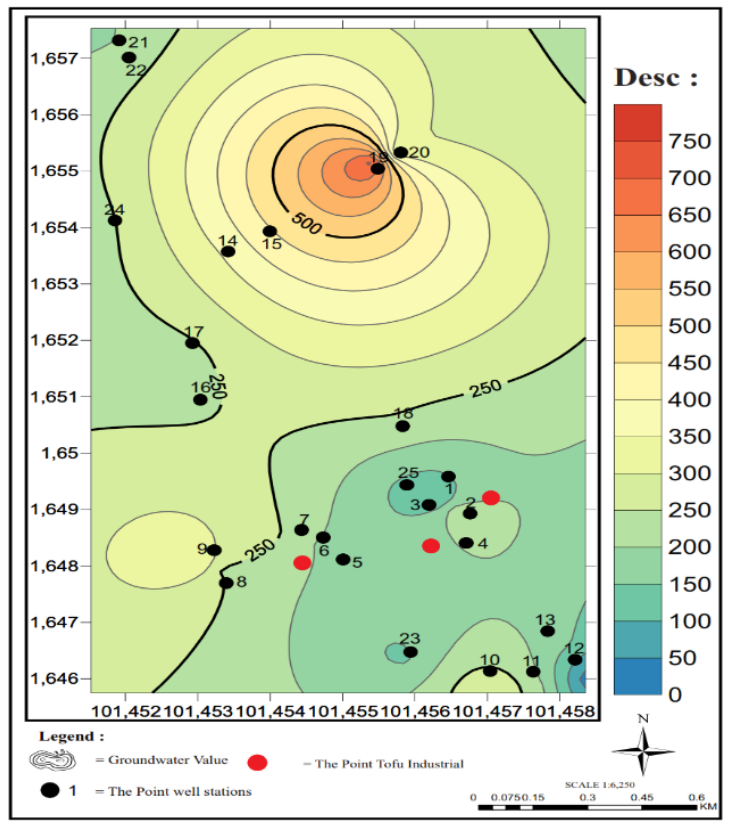

Fig 3. Groundwater TDS distribution map
From Fig.3, it can be seen that the higher TDS values were scattered towards on the north of study area. This was because swampy areas or peat lands contain many chemical elements that can increase dissolved solids in groundwater. Lower TDS values were scattered towards on the south of study area. Sandy areas can be useful as groundwater filtering materials that can reduce dissolved solids.

\subsection{Electrical Conductivity (EC)}

EC value of groundwater ranges from $39-1188 \mu \mathrm{S} / \mathrm{cm}$ with average $396 \mu \mathrm{S} / \mathrm{cm}$. EC value was a function of temperature, type and concentration of dissolved ions. EC value reflects the concentration of dissolved ions in water. The high concentration of dissolved ions in water causes its EC value to be higher.

From Fig.4, it can be seen that higher EC values were scattered towards on the north, while lower EC values were scattered towards on the south of study area. This was because TDS values of groundwater in the north of study area were greater than TDS values of groundwater in the south of study area. This showed that the EC value was directly related to the TDS value.

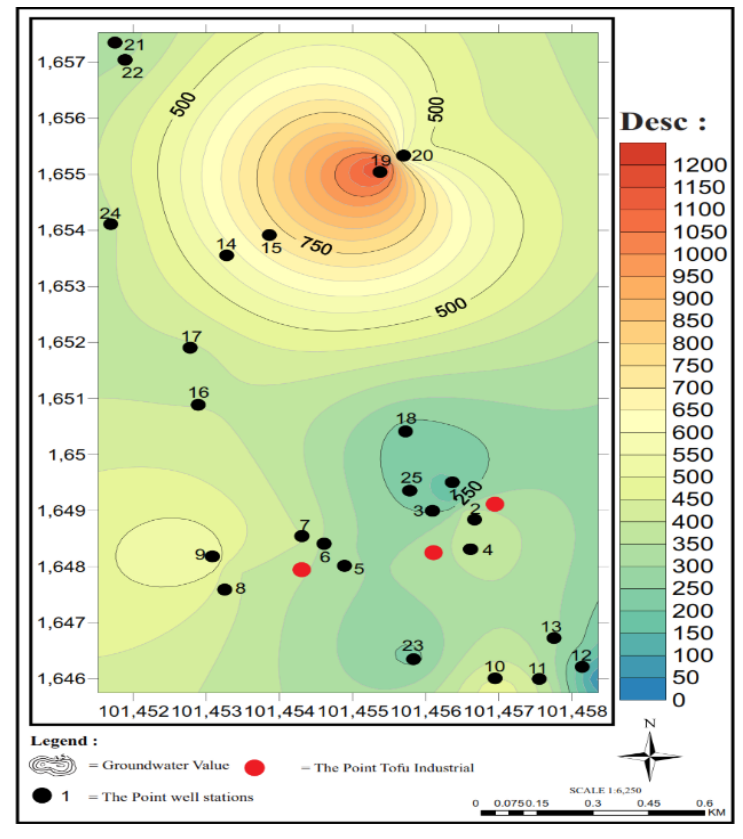

Fig 4. Groundwater EC distribution map

\subsection{Chemical Oxygen Demand (COD)}

COD is the amount of oxygen that needed to oxidize the substances in the water. A high COD value will reduce the dissolved oxygen content in water. Based on Government Regulation, COD concentration $<5 \mathrm{mg} / \mathrm{L}$ (very light pollution), COD 6-9 mg/L (light pollution), COD 10-15 mg/L (moderate pollution), COD > 10-15 mg/L (heavy pollution) (Putra,A.Y., and Yulis, P.A.R., 2019.). COD value in study area range 35$162,13 \mathrm{mg} / \mathrm{L}$ with average $78 \mathrm{mg} / \mathrm{L}$ (Fig.5). It can be concluded that groundwater was classified into heavy pollution category. The high COD value of groundwater was due to the location close the tofu factory, where the liquid waste was immediately disposed without treatment, causing contamination. It also indicated that groundwater has been contaminated by organic material which can come from tofu industrial wastewater. Excessive COD content also will reduce groundwater $\mathrm{pH}$ (Endang, S., Ria, A.,T., N., Anindya, P., F., 2017). It can be seen from groundwater $\mathrm{pH}$ value that almost entirely less than 6,5 . 


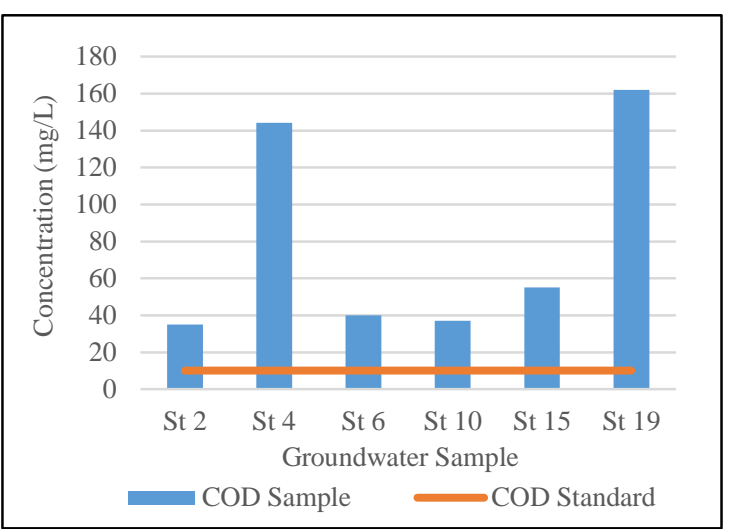

Fig 5. COD value of groundwater

\subsection{Biochemical Oxygen Demand (BOD)}

BOD is the amount of oxygen that required by microbiologist to oxidize substances in water. Based on Government Regulation, BOD concentration $<1 \mathrm{mg} / \mathrm{L}$ (very light pollution), BOD 1-3 mg/L (light pollution), BOD 3-6 $\mathrm{mg} / \mathrm{L}$ (moderate pollution), BOD > $6 \mathrm{mg} / \mathrm{L}$ (heavy pollution) (Putra,A.Y., and Yulis, P.A.R., 2019). BOD value in study area range 3,5-117 mg/L with average $36 \mathrm{mg} / \mathrm{L}$ (Fig.6). It can be concluded that groundwater sample classified into moderateheavy pollution. The very high BOD value in some groundwater samples indicated the possibility of contamination due to the location close the tofu factory. The groundwater has been contaminated by tofu industrial liquid waste which contains various kinds of organic materials. In addition, the high BOD content showed the high level of microorganism in decomposing organic matter contained in groundwater. Excessive BOD content will also reduce $\mathrm{pH}$ value as same as COD (Endang, S., Ria, A.,T., N., Anindya, P., F., 2017).

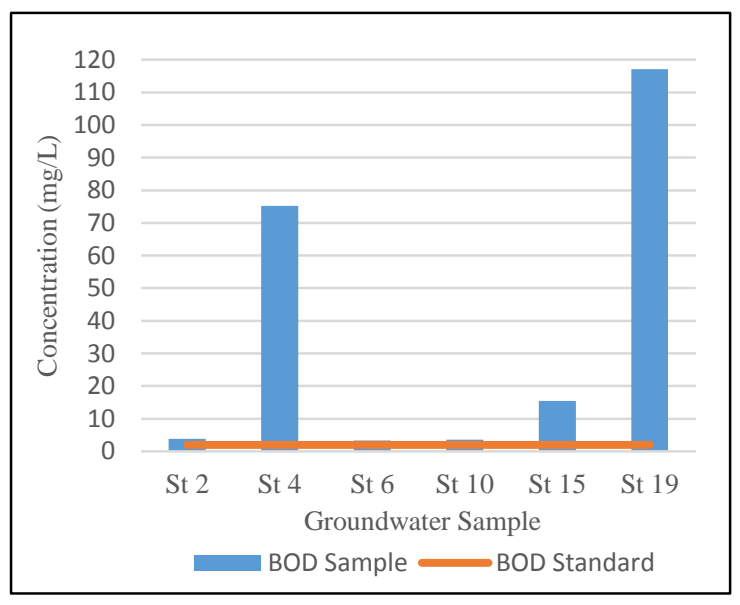

Fig 6. BOD value of groundwater

\section{Conclusion}

Groundwater samples were obtained from dug wells located around tofu industrial factory. Physically, groundwater had temperature average $28,6^{\circ} \mathrm{C}$, TDS $243 \mathrm{mg} / \mathrm{L}$ and EC 396 $\mu \mathrm{S} / \mathrm{cm}$. Almost all groundwater were acidic with $\mathrm{pH}$ average 5,6 and did not meet the drinking water quality requirements according to Health Minister Regulation No. 492/MENKES/PER/IV/2010. Groundwater had COD average $78 \mathrm{mg} / \mathrm{L}$ and BOD average $36 \mathrm{mg} / \mathrm{L}$. Based on Government Regulation No.82 2001, groundwater in study area were classified into moderate-heavy pollution. It indicated that groundwater may have been contaminated by organic material from tofu industrial wastewater. Therefore, groundwater should not be used as a source of drinking water.

\section{Acknowledgements}

The authors would like to give an acknowledgment to the Geological Engineering Laboratory Universitas Islam Riau and the Industrial Research and Standardization Laboratory Padang for their cooperation in conducting this research. Additional thanks to all students who help authors to collect data.

\section{References}

Annapoorna, H., Janardhana, M.R. 2015. Assessment of Groundwater Quality for Drinking Purpose in Rural Areas Surrounding a Defunct Copper Mine. Aquatic Procedia 4, 685-692. https://doi.org/10.1016/ j.aqpro.2015.02.088.

Durgasrilakshmi, H. 2019. Groundwater Quality Assessment in Kattedan Industrial Area, Hyderabad, India. International Journal of Recent Technology and Engineering, 8(1), 3481-3486

Endang, S., Ria, A.,T., N., Anindya, P., F. 2017. Studi Kandungan Bahan Organik pada Beberapa Muara Sungai di Kawasan Ekosistem Mangrove, di Wilayah Pesisir Pantai Utara, Kota semarang, Jawa Tengah. Buletin Oseanografi Marina, 6(1), 29-38.

Firdaus, et., al. 2017. Analisis Kualitas Airtanah Berdasarkan Parameter Kekeruhan, TDS (Total Dissolved Solid), pH, Zat Organik di Wilayah Bukit Batu Putih, Samarinda, Kalimantan Timur. Jurnal Teknologi Mineral, 5(2), 1-4.

Ibrahim, M.N. 2019. Assessing Groundwater Quality for Drinking Purpose in Jordan : Application of Water Quality Index. Journal of Ecological Engineering, 20(3), 101-11. https://doi.org/10.12911/22998993/ 99740

Khan A., Khan M.A. 2018. Groundwater Assessment for Drinking Purpose in Gulistan-e-Johar Town, Karachi, Pakistan. Journal of Geoscience, Engineering, Environment, and Technology, 3(4), 200-207. doi: 10.24273/jgeet.2018.3.4.2086.

Lalitha, B.V., Teja, V.S., Rajesh, V. 2016. A study on Assessment of Groundwater Quality and Its Suitability for Drinking in Shivajipalem Area Visakhapatnam, A.P. International Journal of Engineering Development and Research, 4(2), 1618-1621.

Mairizki, F., Cahyaningsih, C. 2016. Groundwater Quality Analysis in The Coastal of Bengkalis City Using Geochemistry Approach. International Journal of Engineering and High-End Technology, 1(2), 82-87

Naslilmuna, M., Muryani, C., Santoso, S. 2018. Analisis Kualitas Air Tanah dan Pola Konsumsi Masyarakat Sekitar Industri Kertas PT Jaya Kertas Kecamatan Kertosono Kabupaten Nganjuk. Jurnal GeoEco, 4(1), 5158. https://doi.org/10.20961.ge.v4i1. 19176

Nurhalisa, Ardiansah, H., Risma. 2017. Analisis Kadar COD dan BOD pada Air Sumur Akibat Buangan Limbah Pabrik Tapioka di Kec. Palangga Kab. Gowa. Jurnal Media Laboran, 7(2), 22-27

Putra, A., Yulis, P.,A.,R. 2019. Kajian Kualitas Air Tanah Ditinaju dari Parameter $\mathrm{pH}$, Nilai COD dan BOD pada Desa Teluk Nilap Kecamatan Kubu Babussalam rokan Hilir Provinsi Riau. Jurnal Riset Kimia, 10(2), 103-109. https://doi.org/10.25077/jrk.v10i2.337

Putra, A.Y., Mairizki, F. 2019. Analisis Warna, Derajat Keasaman dan Kadar Logam Besi Air Tanah di Kecamatan Kubu Babussalam, Rokan Hilir, Riau. Jurnal Katalisator, 4(1), 9-14. http://doi.org/10.22216/jk.v4i1.4024

Putra, A.,Y., Mairizki, F. 2020. Groundwater Quality Assessment for Drinking Purpose Based on 
Physicochemical Analysis in Teluk Nilap Area, Rokan Hilir, Riau, Indonesia. Journal of Geoscience, Engineering, Environment and Technology, 5(3) : 170174. https://doi.org/10.25299/jgeet.2020.5.3.5488

Putra, D.B.E., Yuskar, Y., Kausarian, H., Yaacob, W,Z., Hadian, M.S.D. 2019. Saltwater Intrusion Zone Mapping on Shallow Groudwater Aquifer in Selat Baru, Bengkalis Island, Indonesia. Journal of Geoscience, Engineering, Environment, and Technology, 4(1), 16-21. doi:10.25299/jgeet.2019.4.1.2672.

Risky, D.P., Artini, N.P.R., Aryasa, I.W.T. 2017. Penelitian Pendahuluan Kualitas Air Tanah di Banjar Suwung Batan Kendal, Kelurahan Sesetan, Kota Denpasar. Medicamento, 3(1), 39-43

Rout, C., Baldev, S. 2018. Assesment of Groundwater Quality for Suitability of Industrial Purposes. International Research Journal of Environmental Sciences, 7(3), 8-16.

Samira, M., Amina, M., El., A., Moncef, G. 2019. Inferred Industrial and Agricultural activities Impact on Groundwater Quality of Skhira Coastal Phreatic Aquifer in Southeast of Tunisia (Mediteranean Region). Geofluids, 1-9. https://doi.org/10.1155/2019/9465498.

Sharma, S., Sharma, G., Rajesh Kr., Y. 2016. Impact of Industrial Development on Groundwater Quality-A Case Study of Impact of Effluent from Vishakarma Industrial area, Jaipur on Ground Water. Bulletin of Environment, Pharmacology and Life Sciences, 5(7), 12-15.

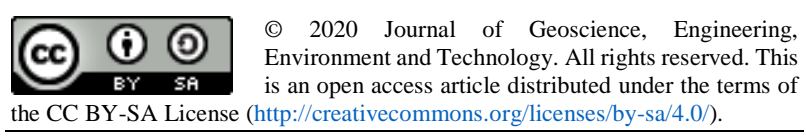

